University of Nebraska - Lincoln

DigitalCommons@University of Nebraska - Lincoln

$5-1-2021$

\title{
Effects of residue removal and tillage on greenhouse gas emissions in continuous corn systems as simulated with RZWQM2
}

\author{
Haomiao Cheng \\ Yangzhou University \\ Kexin Shu \\ Yangzhou University \\ Zhiming Qi \\ McGill University, Macdonald Campus, zhiming.qi@mcgill.ca \\ Liwang Ma \\ USDA Agricultural Research Service \\ Virginia L. Jin \\ USDA Agricultural Research Service - Lincoln, Nebraska
}

See next page for additional authors

Follow this and additional works at: https://digitalcommons.unl.edu/usdaarsfacpub

Part of the Agriculture Commons

Cheng, Haomiao; Shu, Kexin; Qi, Zhiming; Ma, Liwang; Jin, Virginia L.; Li, Youjia; Schmer, Marty R.; Wienhold, Brian J.; and Feng, Shaoyuan, "Effects of residue removal and tillage on greenhouse gas emissions in continuous corn systems as simulated with RZWQM2" (2021). Publications from USDA-ARS / UNL Faculty. 2508.

https://digitalcommons.unl.edu/usdaarsfacpub/2508

This Article is brought to you for free and open access by the U.S. Department of Agriculture: Agricultural Research Service, Lincoln, Nebraska at DigitalCommons@University of Nebraska - Lincoln. It has been accepted for inclusion in Publications from USDA-ARS / UNL Faculty by an authorized administrator of DigitalCommons@University of Nebraska - Lincoln. 


\section{Authors}

Haomiao Cheng, Kexin Shu, Zhiming Qi, Liwang Ma, Virginia L. Jin, Youjia Li, Marty R. Schmer, Brian J. Wienhold, and Shaoyuan Feng 
Research article

\title{
Effects of residue removal and tillage on greenhouse gas emissions in continuous corn systems as simulated with RZWQM2
}

\author{
Haomiao Cheng ${ }^{\mathrm{a}, \mathrm{e}}$, Kexin Shu ${ }^{\mathrm{a}}$, Zhiming Qi ${ }^{\mathrm{b}, *}$, Liwang Ma ${ }^{\mathrm{c}}$, Virginia L. Jin ${ }^{\mathrm{d}}$, Youjia Li ${ }^{\mathrm{b}}$, \\ Marty R. Schmer ${ }^{d}$, Brian J. Wienhold ${ }^{\mathrm{d}}$, Shaoyuan Feng ${ }^{\mathrm{e}}$ \\ a School of Environmental Science and Engineering, Yangzhou University, Yangzhou, 225127, China \\ ${ }^{\mathrm{b}}$ Department of Bioresource Engineering, McGill University, Sainte-Anne-de-Bellevue, QC, H9X 3V9, Canada \\ ${ }^{\mathrm{c}}$ USDA-ARS, Rangeland Resources and Systems Research Unit, Fort Collins, CO, 80526, USA \\ ${ }^{\mathrm{d}}$ USDA-ARS, Agroecosystem Management Research Unit, Lincoln, NE, 68583-0937, USA \\ ${ }^{\text {e }}$ School of Hydraulic Science and Engineering, Yangzhou University, Yangzhou, 225127, China
}

\section{A R T I C L E I N F O}

\section{Keywords:}

Carbon dioxide

Nitrous oxide

Conservation management practices

Stover residue retention

Tillage

RZWQM2

\begin{abstract}
A B S T R A C T
Agricultural production is a major source of carbon dioxide $\left(\mathrm{CO}_{2}\right)$ and nitrous oxide $\left(\mathrm{N}_{2} \mathrm{O}\right)$ globally. The effects of conservation practices on soil $\mathrm{CO}_{2}$ and $\mathrm{N}_{2} \mathrm{O}$ emissions remain a high degree of uncertainty. In this study, soil $\mathrm{CO}_{2}$ and $\mathrm{N}_{2} \mathrm{O}$ emissions under different residue and tillage practices in an irrigated, continuous corn system, were investigated using the Root Zone Water Quality Model (RZWQM2). Combinations of no/high stover removal (NR and HR, respectively) and no-till/conventional tillage (NT and CT, respectively) field experiments were tested over the four crop-years (Apr. 2011-Apr. 2015). The model was calibrated using the NRCT, and validated with other treatments. The simulation results showed that soil volumetric water content (VWC) in the NR treatments (i.e., NRCT and NRNT) was 1.3\%-1.9\% higher than that in the HR treatments (i.e., HRCT and HRNT) averaged across the four years. A higher amount of $\mathrm{CO}_{2}$ and $\mathrm{N}_{2} \mathrm{O}$ emissions were simulated in the NRCT across the four years (annual average: $7034 \mathrm{~kg} \mathrm{C} / \mathrm{ha} / \mathrm{yr}$ for $\mathrm{CO}_{2}$ and $3.8 \mathrm{~kg} \mathrm{~N} / \mathrm{ha} / \mathrm{yr}$ for $\mathrm{N}_{2} \mathrm{O}$ ), and lower emissions were in the HRNT (annual average: $6329 \mathrm{~kg} \mathrm{C} / \mathrm{ha} / \mathrm{yr}$ and $3.7 \mathrm{~kg} \mathrm{~N} / \mathrm{ha} / \mathrm{yr}$ for $\mathrm{N}_{2} \mathrm{O}$ ). A long-term simulation (2001-2015) suggested that the $\mathrm{CO}_{2}$ and $\mathrm{N}_{2} \mathrm{O}$ emissions were closely correlated with the stover removal degree (SRD), tillage, VWC, soil temperature (ST), years in management (Y), and fertilizer application. Stover and tillage practices had cumulative effects on $\mathrm{CO}_{2}$ emissions. The simulated annual $\mathrm{CO}_{2}$ emissions in 1st year from NRCT, NRNT, and HRCT were $7.8 \%, 0.0 \%$, and $7.7 \%$ higher than that from HRNT, respectively; then the emissions in 15 th year were $63.6 \%, 47.7 \%$, and $29.1 \%$ higher, respectively. Meanwhile, there were no cumulative effects on $\mathrm{N}_{2} \mathrm{O}$ emissions. The results also demonstrated that the RZWQM2 is a promising tool for evaluating the long-term effects of $\mathrm{CO}_{2}$ and $\mathrm{N}_{2} \mathrm{O}$ emissions on different conservation practices.
\end{abstract}

\section{Introduction}

Greenhouse gas (GHG) emissions (e.g., carbon dioxide $\left(\mathrm{CO}_{2}\right)$, nitrous oxide $\left(\mathrm{N}_{2} \mathrm{O}\right)$, and methane $\left(\mathrm{CH}_{4}\right)$ ) have contributed to global warming and impacted precipitation and temperatures on the Earth's surface. Specially, the global atmospheric $\mathrm{CO}_{2}$ concentration has increased by $\sim 21 \%$ from 1980 (339 ppm) to 2019 (410 ppm); other GHGs have also increased rapidly (www.esrl.noaa.gov). Agricultural production systems are one of the major contributors to $\mathrm{CO}_{2}$ and $\mathrm{N}_{2} \mathrm{O}$ emissions worldwide, with $\sim 25 \%$ and $\sim 75 \%$ of the total $\mathrm{CO}_{2}$ and $\mathrm{N}_{2} \mathrm{O}$ emissions, respectively (Pachauri et al., 2014). Recent research has suggested potential agricultural practices to reduce emissions without reducing food production (Abbas et al., 2020; IPCC, 2007; De Stefano and Jacobson, 2018). Thus, it has direct practical significance to quantify the effects of agricultural practices on $\mathrm{CO}_{2}$ and $\mathrm{N}_{2} \mathrm{O}$ emissions.

Conservation management practices (i.e., stover retention and notill) have been recommended in the past two decades for the sequestration of soil organic carbon (SOC) and for reducing wind and water erosion (Kumara et al., 2020; Wang et al., 2020). However, the effects of stover retention and no-till on GHG emissions are mixed. It has been reported that soil $\mathrm{CO}_{2}$ and $\mathrm{N}_{2} \mathrm{O}$ emissions may decrease (Abdalla et al., 2019; Ma et al., 2019; Sanz-Cobena et al., 2017), increase (Fan et al.,

\footnotetext{
* Corresponding author.

E-mail address: zhiming.qi@mcgill.ca (Z. Qi).
} 
2018; Jin et al., 2014, 2017; Locker et al., 2019), or remain unchanged (Dendooven et al., 2012) depending on different conservation practices. On one hand, conservation practices can potentially decrease emissions by minimizing soil disturbance and boosting the sequestration of SOC (Lee et al., 2020; Wienhold et al., 2016). On the other hand, a high biomass production could be offset by the SOC losses due to decomposition if a management system has a low potential to sequester C (Follett et al., 2013; Schmer et al., 2014). Meanwhile, the $\mathrm{CO}_{2}$ and $\mathrm{N}_{2} \mathrm{O}$ emissions are closely coupled with changes in the soil $\mathrm{C}$ and $\mathrm{N}$ cycling (Ma et al., 2019). The spatial and temporal distributions of soil volumetric water content (VWC), soil temperature (ST), and soil hydraulic properties in the profile vary with the stover and tillage practices, leading to uncertainty in the soil $\mathrm{C}$ and $\mathrm{N}$ cycling and the prediction of $\mathrm{CO}_{2}$ and $\mathrm{N}_{2} \mathrm{O}$ emissions (Hu et al., 2017; Oertel et al., 2016). Moreover, conservation practices may take several years to impact soil properties $(\geq 4$ years generally), but most experiments in the literature lasted for only 2-3 years (Abdalla et al., 2019). Therefore, comprehensive strategies and long-term observation are required to predict $\mathrm{CO}_{2}$ and $\mathrm{N}_{2} \mathrm{O}$ emissions.

The Root Zone Water Quality Model (RZWQM2) is a process-based comprehensive agricultural system model based on highly frequent spatial and temporal measurements of the driving variables (Ahuja et al., 2000). This model has shown good simulations of the VWC, ST, yield and nitrogen dynamics within the soil profile as influenced by conservation practices (Ding et al., 2020; Yang et al., 2020a, 2020b). However, the previous studies did not thoroughly test the model, especially the effects of conservation practices on nutrient cycling and GHG emissions. Compared with other process-based simulation models, the performance of GHG algorithms in RZWQM2 was significantly improved by comparing and coupling four mainstream GHG algorithms in DAYCENT, NOE, WNMM and FASSET (Fang et al., 2015). Recently, Gillette et al. (2017, 2018) tested the GHG component in RZWQM2 under different $\mathrm{N}$ input management with good results. Yang et al. (2019) quantified soil $\mathrm{CO}_{2}$ emissions and evaluated different decisions (on the type and timing of fertilization) by using the RZWQM2. In addition, Jiang et al. (2019) estimated $\mathrm{CO}_{2}$ and $\mathrm{N}_{2} \mathrm{O}$ emissions in a subsurface-drained field and explored the optimal $\mathrm{N}$ fertilization to achieve a higher $\mathrm{N}$-use efficiency. Their studies were mainly focused on fertilizer decisions, but residue management, tillage, and their combined effects on GHG emissions have not been evaluated yet using the RZWQM2.

The objective of this study was to evaluate the effects of stover management and tillage practices on $\mathrm{CO}_{2}$ and $\mathrm{N}_{2} \mathrm{O}$ emissions based on a 4-year dataset from an irrigated continuous corn (Zea mays L.) production system by using the RZWQM2. Simulated VWC, ST, yield, and $\mathrm{CO}_{2}$ and $\mathrm{N}_{2} \mathrm{O}$ emissions were calibrated and validated by testing different stover management (stover retention/removal) and tillage practices (notillage/conventional tillage). The variability of long-term $\mathrm{CO}_{2}$ and $\mathrm{N}_{2} \mathrm{O}$ emissions caused by the different stover and tillage managements were also quantified.

\section{Materials and methods}

\subsection{Site description and field experiments}

A cornfield experiment was conducted at the University of Nebraska Eastern Nebraska Research and Extension Center $\left(41^{\circ} 9^{\prime} 43^{\prime \prime} \mathrm{N}\right.$, $96^{\circ} 24^{\prime} 41^{\prime \prime} \mathrm{W}, 349 \mathrm{~m}$ asl), Ithaca, NE, USA. The soils at this site consisted of silt loams of the Tomek (fine, smectitic, mesic Pachic Argiudoll) and Filbert (fine, smectitic, mesic Vertic Argialboll) series. The average initial soil $\mathrm{pH}$, total $\mathrm{N}$ concentration, and total $\mathrm{C}$ concentration in the top $15 \mathrm{~cm}$ of the soil profile were $7.1,1.6 \mathrm{~g} \mathrm{~N} / \mathrm{kg}$, and $19.3 \mathrm{~g} \mathrm{C} / \mathrm{kg}$, respectively. The monthly average air temperatures and cumulative precipitation are shown in Fig. S1 (Supplementary information). The average annual air temperature and precipitation during the 4 cropyears were $10.4{ }^{\circ} \mathrm{C}$ and $613 \mathrm{~mm}$, respectively.
A $3 \times 2$ factorial combination of three stover removal rates (no removal (NR) vs. high removal (HR)) and two tillage treatments (conventional tillage (CT) vs. no-till (NT)) with randomized complete block design were tested over the four crop-years (i.e., NRCT, HRCT, NRNT, and HRNT in this study) from April 28, 2011 to April 30, 2015 (Table S1, supplementary information) with details available in Jin et al. (2017) and Schmer et al. (2014). The stover was harvested from all the corn rows in the HR treatments (i.e., HRCT and HRNT). The corn stover was harvested in the fall (during late October or November) and was carried out using a flail chopper, preserving $10 \mathrm{~cm}$ of corn stover stubble. The stover in the NR treatments (i.e., NRCT and NRNT), instead, remained on the soil surface. Continuous corn (cultivar 'Pioneer 1498XR') was planted in each plot $(9 \mathrm{~m} \times 15.2 \mathrm{~m})$ at a density of 74350 seeds/ha to a depth of $5 \mathrm{~cm}$ in May of each year. The $\mathrm{N}$ fertilizer in the form of granular urea (46-0-0) was applied at the same rate (202 kg N/ha/year) each year (Table S1, supplementary information). Total amount of irrigation water applied (by using a linear move sprinkler) was $38 \mathrm{~mm}$ in 2011, $166 \mathrm{~mm}$ in 2012, $121 \mathrm{~mm}$ in 2013, and $114 \mathrm{~mm}$ in 2014 (Fig. S1).

Soil $\mathrm{CO}_{2}$ and $\mathrm{N}_{2} \mathrm{O}$ emissions were determined by using standardized gas sampling designs and data processing protocols by the United States Department of Agriculture- Agricultural Research Service's (USDA-ARS) Greenhouse gas Reduction through Agricultural Carbon Enhancement network (GRACEnet) (Parkin and Venterea, 2010). Briefly, static vented gas sampling chambers $(52.7 \mathrm{~cm} \times 32.4 \mathrm{~cm})$ were installed in each treatment plot to collect soil GHG emissions. Each sampling event was performed before midmorning of each sampling date. Gas samples were collected from the headspace of the chambers using a syringe, and then injected into evacuated vials at 4 evenly-spaced 10 -min intervals. $\mathrm{CO}_{2}$ and $\mathrm{N}_{2} \mathrm{O}$ concentrations in the headspace gas samples were measured within 10 days by using an autosampler (CombiPAL; CTC Analytics, Zwingen, Switzerland) connected to a gas chromatograph (450-GC; Varian, Middelburg, the Netherlands) equipped with a thermal conductivity detector for $\mathrm{CO}_{2}$ and an electron capture detector for $\mathrm{N}_{2} \mathrm{O}$. Details information were reported in previous studies (Jin et al., 2014, 2017).

At each sampling event, VWC and ST at $15 \mathrm{~cm}$-depth were measured using a handheld time domain reflectometer (FieldScout TDR 300; Spectrum Technologies, Aurora, IL, USA) with a site-specific calibration and digital thermometer, respectively. The sampling events were conducted at intervals of $\sim 7$ days during the growing season (May-September) and with a greater frequency $(\sim 2$ days $)$ following field management practices (i.e., tillage, irrigation, and fertilization), with a total of 85 events between April 2011 and April 2015. During the nongrowing seasons, the sampling events were conducted monthly (as allowed by weather and ground conditions). The initial physicochemical properties (i.e., bulk density ( $\rho$ ), particle size distribution (PSD), and SOC along the soil profile were measured from soil cores collected from each plot as shown in Schmer et al. (2014) and Stewart et al. (2019).

\subsection{RZWQM2 overview, model input, and calibration}

\subsubsection{Model description}

The RZWQM2 is a process-based agricultural model coupled with DASSAT4.0 crop growth modules (Ma et al., 2000, 2006). Specifically, it employs the Richards' equation to simulate water redistribution throughout the soil profile and the Green-Ampt equation to calculate the infiltration of precipitation and irrigation water (Ahuja et al., 2000). The extended Shuttle-Wallace equation is used to predict the potential evapotranspiration (PET) that takes into account partial canopy cover and surface residue cover. Crop residue may be incorporated into soil via tillage or degraded on the soil surface at a lower rate (Ahuja et al., 2000). The tillage also reduces soil bulk density $(\rho)$ and eliminates continuous macropore channels. The Organic Matter and NItrogen (OMNI) module in the RZWQM2 is used to simulate the nutrient cycling and GHG emissions. The OMNI module contains two surface residue pools (i.e., slow and fast) and three soil humus pools (i.e., slow, intermediate, and 
fast soil humus pools). The main processes of the $\mathrm{C}$ and $\mathrm{N}$ cycling were inter-pool transfer, nitrification, denitrification, mineralization and immobilization, aerobic and anaerobic decay, and microbial biomass growth and death. The basic equations and algorithms of the OMNI module were reported in previous studies (Ahuja et al., 2000; Cameira et al., 2007; Ma et al., 1998). The OMNI module has shown to be effective in simulating the long-term effects of management on soil $\mathrm{C}$ and N cycling and soil-water-plant processes (Chen et al., 2019; Jiang et al., 2019).

\subsubsection{Model initialization and calibration}

The RZWQM2 (current version 4.2) was employed to calibrate and validate against measured VWC, ST, yield, and daily $\mathrm{CO}_{2}$ and $\mathrm{N}_{2} \mathrm{O}$ emissions under various residue and tillage treatments in this study. The model was calibrated with data collected from the NRCT treatment from 2011 to 2014. The remaining treatments (i.e., HRCT, NRNT, and HRNT) were used to validate the model.

Long-term daily weather data needed for running the model (i.e., minimum/maximum air temperature, wind speed, relative humidity, precipitation, and solar radiation) were obtained from a weather station (Station ID: Meadagrofarm) located $200 \mathrm{~m}$ from the experimental field. The 200-cm-deep soil profile used in this simulation was divided into 8 horizons: $0-8,8-15,15-30,30-60,60-90,90-120,120-150$, and $150-200 \mathrm{~cm}$. The initial $\rho$, PSD, and SOC in the soil profile were set to the observed value from the observations in Nov. 2010. Before running the RZWQM2 model, a long-term "warm-up" run was conducted to obtain reasonable results for the SOC decomposition rate and microbial populations by running the model three times using the current 4-year weather data (the equivalent of $\geq 10$ years) (Ma et al., 1998; Schmer et al., 2014). Then, simulations were run using residue and the inorganic $\mathrm{N}$ profiles obtained at the end of the initialization period (Jiang et al., 2019; Yang et al., 2019). The stabilized initial nutrient concentrations are listed in Table S2 (Supplementary information).

The soil hydraulic parameters were calibrated based on the observed VWC data (listed in Table S3, supplementary information). For a better simulation of the VWC, we calibrated the soil root growth factors for each layer (Table S3, supplementary information) (Qi et al., 2011). The final calibrated VWC for each layer at the beginning of simulation was $0.24,0.25,0.19,0.30,0.31,0.31,0.31$ and $0.29 \mathrm{~cm}^{3} / \mathrm{cm}^{3}$. Moreover, the plant parameters were manually adjusted to fit the observed yield (Table S4, supplementary information) (Qi et al., 2013). The three soil humus pools considered for the OMNI module were: the fast soil humus pool (2\%), the intermediate soil humus pool (18\%), and the slow soil humus pool $(80 \%)$. Other calibrated nutrient parameters of OMNI module are listed in Table S5 and S6 (Supplementary Information).

\subsection{Quantification of the long-term impacts of stover and tillage practices}

After calibrating and validating RZWQM2 with experimental data (Apr. 2011-Apr. 2015), the long-term $\mathrm{CO}_{2}$ and $\mathrm{N}_{2} \mathrm{O}$ emissions were predicted based on the existing field conditions. Fifteen-year historical weather data (2001-2015) obtained from the same station were used for the validated RZWQM2 (Fig. S2, supplementary information). The planting and harvest dates, tillage, fertilizer applications, and irrigation data of the experimental site followed actual agronomic management practices from 2001 to 2015 (Wienhold et al., 2016). The effects of long-term conventional versus conservation tillage scenarios on annual $\mathrm{CO}_{2}$ and $\mathrm{N}_{2} \mathrm{O}$ emissions were investigated and quantified: (i) NT and CT managements; (ii) eleven stover removal degrees (SRDs) from 0 to $100 \%$ at $10 \%$ interval in both NT and CT managements.

\subsection{Model performance and testing}

The performance of the RZWQM2 for the prediction of the VWC, ST, and $\mathrm{CO}_{2}$ and $\mathrm{N}_{2} \mathrm{O}$ emissions was evaluated using the following statistical criteria: the percent bias (PBIAS), the Nash-Sutcliffe efficiency (NSE), the index of agreement (IoA), and the determination coefficient $\left(\mathrm{R}^{2}\right)$. The calculation formulas are as follow:

$$
\begin{aligned}
& \mathrm{PBIAS}=\frac{\sum_{i=1}^{N}\left(O_{i}-P_{i}\right)}{\sum_{i=1}^{N} O_{i}} \times 100 \\
& \mathrm{NSE}=1-\frac{\sum_{i=1}^{N}\left(O_{i}-P_{i}\right)^{2}}{\sum_{i=1}^{N}\left(O_{i}-\bar{O}\right)^{2}} \\
& \mathrm{IoA}=1-\frac{\sum_{i=1}^{N}\left(O_{i}-P_{i}\right)^{2}}{\sum_{i=1}^{N}\left(\left|P_{i}-\bar{P}\right|+\left|O_{i}-\bar{O}\right|\right)^{2}} \\
& \mathrm{R}^{2}=\frac{\sum_{i=1}^{N}\left(O_{i}-\bar{O}\right)\left(P_{i}-\bar{P}\right)}{\sqrt{\sum_{i=1}^{N}\left(O_{i}-\bar{O}\right)^{2} \sum_{i=1}^{N}\left(P_{i}-\bar{P}\right)^{2}}}
\end{aligned}
$$

Where $P_{i}$ and $O_{i}$ represent the $i$-th paired simulated and observed values, respectively, $N$ the number of observations, and $\bar{P}$ and $\bar{O}$ the average simulated and observed data pairs, respectively.

The PBIAS was used to evaluate the difference between the mean observed and simulated data: the results were considered satisfactory if this difference was within $\pm 15 \%$ (Hanson et al., 1999). The NSE was applied to normalize the residual variance between the observed and simulated data: NSE $>0.5$ indicated that the simulated data were in good agreement with the observed ones, and that the performance of the model may not be satisfactory when some peaks are underestimated (Nash and Sutcliffe, 1970). The IoA and $\mathrm{R}^{2}$ were used to evaluate the model accuracy: the model was considered satisfactory when IoA $>0.7$ or $\mathrm{R}^{2}>0.5$ (Ma et al., 2012).

Due to the relatively low number of crop yield values per treatment combination $(N=4)$, the relative error (RE) was used to evaluate the model accuracy, which was calculated as $\mathrm{RE}=\left(P_{i}-O_{i}\right) / O_{i}$. Cumulative annual GHG emissions were estimated by linear interpolation of flux rates between observed or simulated sampling dates, then summing daily rates over each crop-year (i.e., trapezoidal integration method). A Wilcoxon test was used to evaluate statistical difference between the observed or simulated results of four treatments. A stepwise multiple linear regression (MLR) was applied to simulated data to analyze the effects of stover and tillage managements on long-term $\mathrm{CO}_{2}$ and $\mathrm{N}_{2} \mathrm{O}$ emissions by using SPSS 20.0. Simulated long-term data were randomly divided into three groups, then a cross-validation procedure was conducted to evaluate the predictive skill in the MLR. A $p$-value $<0.05$ were considered statistically significant.

\section{Results and discussion}

\subsection{VWC, ST, and crop yield}

The observed and simulated daily VWC and ST at the $15 \mathrm{~cm}$ soil depth are plotted in Fig. 1, with simulation statistics shown in Table 1. The simulated VWC in each treatment ranged between 0.17 and 0.32 $\mathrm{cm}^{3} / \mathrm{cm}^{3}$ during the 4 crop-years. Based on the PBIAS, the VWC was underestimated by $1.0 \%$ for the NRCT in the model calibration, overestimated by $0.2 \%$ for the HRCT, and underestimated by $3.8 \%$ and $4.2 \%$ for the NRNT and HRNT treatments, respectively, in model validation. Although the NSE of the VWC was $\sim 0.35(<0.5)$, the simulated VWC was considered adequate in terms of PBIAS (which was comprised between $-0.17 \%$ and $-4.18 \%)$, IoA $(>0.64)$, and $\mathrm{R}^{2}(>0.58)$.

In all treatments, stover and tillage practices caused significant differences in the observed VWC $(p<0.01)$. Both observed and simulated VWC for the NR treatments were significantly higher than that for the HR treatments $(p<0.01)$ (Fig. 1a). The average observed VWC $\left(\mathrm{Ob}_{\mathrm{VWC}}\right)$ and average simulated VWC ( $\mathrm{Sim}_{\mathrm{VWC}}$ ) for the NRCT were $2.6 \%$ and $1.3 \%$ higher, respectively, than those for the HRCT, while the Ob $\mathrm{VwC}_{\mathrm{VwC}}$ 


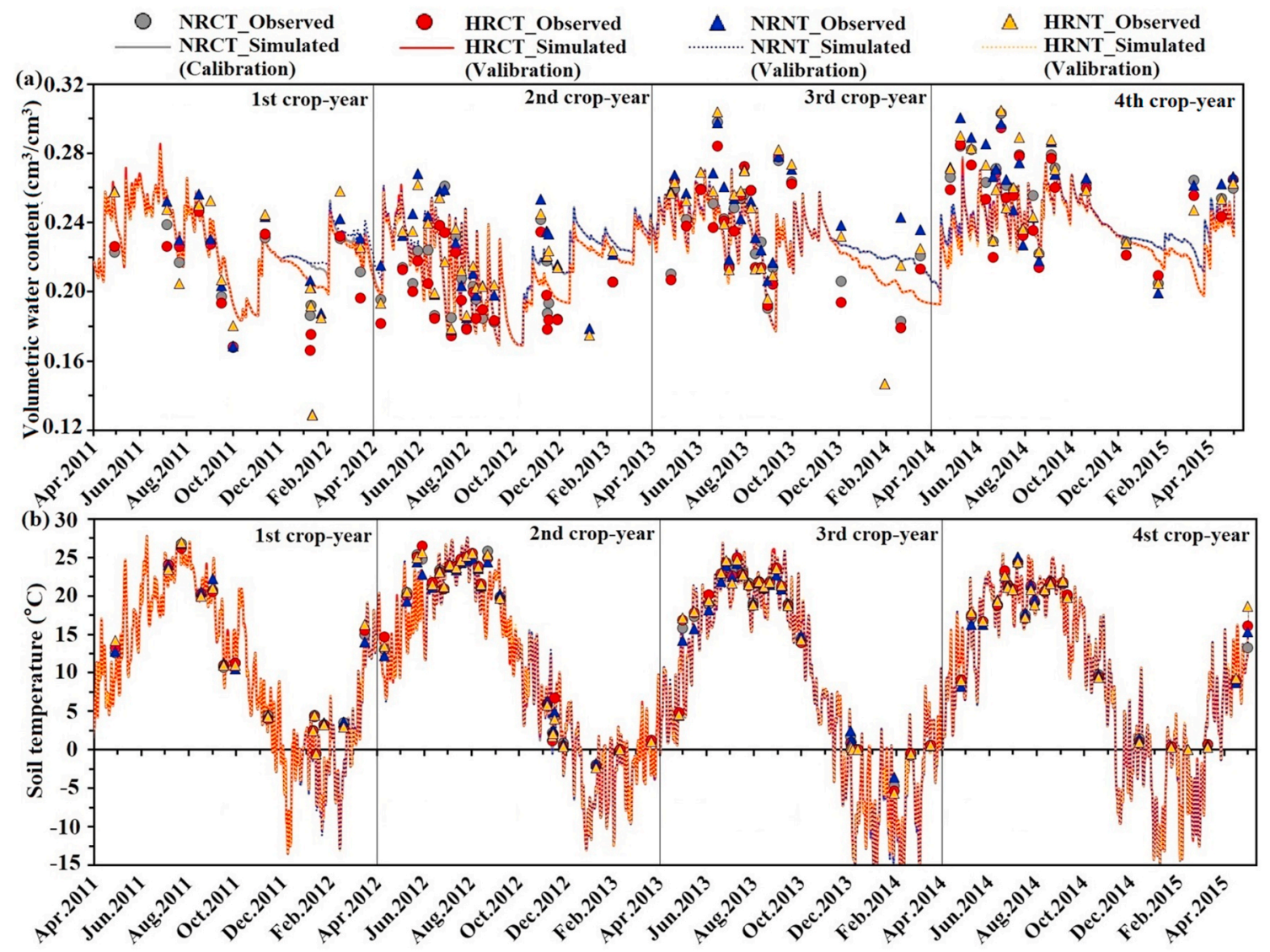

Fig. 1. Observed and RZWQM2-simulated VWC $\left(\mathrm{cm}^{3} / \mathrm{cm}^{3}\right)$ and soil temperature $(\mathrm{ST})\left({ }^{\circ} \mathrm{C}\right)$ at a depth of $15 \mathrm{~cm}$ in the calibration (NRCT treatment) and validation phases (HRCT, NRNT, and HRNT treatments). NRCT: no stover removal + conventional tillage; HRCT: high stover removal + conventional tillage; NRNT: no stover removal + no-till; HRNT: high stover removal + no-till.

Table 1

Statistical criteria (i.e., PBIAS, NSE, IoA, $\mathrm{R}^{2}$, and RMSE) results obtained by comparing the observed and simulated VWC $\left(\mathrm{cm}^{3} / \mathrm{cm}^{3}\right)$ and ST $\left({ }^{\circ} \mathrm{C}\right)$ for each treatment.

\begin{tabular}{|c|c|c|c|c|c|c|c|c|c|c|c|c|}
\hline \multirow[t]{2}{*}{ Treatments } & \multicolumn{6}{|l|}{ VWC } & \multicolumn{6}{|l|}{ ST } \\
\hline & $\mathrm{Ob}_{\mathrm{vwc}}$ & $\operatorname{Sim}_{\mathrm{Vwc}}$ & PBIAS & NSE & IoA & $\mathrm{R}^{2}$ & $\mathrm{Ob}_{\mathrm{ST}}$ & $\operatorname{Sim}_{\mathrm{ST}}$ & PBIAS & NSE & IoA & $\mathrm{R}^{2}$ \\
\hline NRCT & 0.231 & 0.229 & $1.0 \%$ & 0.39 & 0.73 & 0.63 & 15.04 & 14.13 & $6.0 \%$ & 0.90 & 0.98 & 0.96 \\
\hline HRCT & 0.225 & 0.226 & $-0.2 \%$ & 0.43 & 0.76 & 0.66 & 15.12 & 14.16 & $6.3 \%$ & 0.90 & 0.98 & 0.96 \\
\hline HRNT & 0.234 & 0.225 & $4.2 \%$ & 0.33 & 0.70 & 0.64 & 15.11 & 15.11 & $6.3 \%$ & 0.90 & 0.98 & 0.96 \\
\hline
\end{tabular}

VWC: soil volumetric water content $\left(\mathrm{cm}^{3} / \mathrm{cm}^{3}\right)$, ST: soil temperature $\left({ }^{\circ} \mathrm{C}\right) . \mathrm{Ob}_{\mathrm{VWC}}$ and $\mathrm{Ob}_{\mathrm{ST}}$ : the observed average value of VWC and ST, Sim $\mathrm{Avg}_{\text {and }}$ Sim $\mathrm{ST}_{\mathrm{ST}}$ the simulated average value of VWC and ST. The notations used here are same as those in Fig. 1.

and $\mathrm{Sim}_{\mathrm{VWC}}$ of VWC for the NRNT were $1.7 \%$ and $1.7 \%$ higher than those obtained for the HRNT, respectively (Table 1). These results were mainly attributed to the crop residue cover, which decreased PET as calculated by the extended Shuttleworth-Wallace equation in RZWQM2 (Abdalla et al., 2019; Ahuja et al., 2000). Additionally, the Ob $\mathrm{vwC}_{\mathrm{vw}}$ in the CT treatments were $1.3 \%-5.8 \%$ lower than that in the NT treatments. However, there was no significant correlation between the simulated VWC between NRCT and NRNT $(p>0.05)$ or between HRCT and HRNT $(p>0.05)$. Although tillage is expected to reduce soil bulk density $(\rho)$ and destroy macropores, these effects are temporary and are restored with rainfall. Similar phenomena were also obtained in previous studies (Zhang et al., 2016; Gillette et al., 2017).

In contrast to the VWC, predicted ST were in better agreement with the observed data (Fig. 1b). The PBIAS, NSE, IoA, and $\mathrm{R}^{2}$ of the simulated and measured ST values were $\sim 6.1 \%, 0.90,0.98$, and 0.96 , respectively, indicating ST was well-simulated. No significant differences in the observed or simulated ST were found among the four treatments $(p>0.05)$, similar to findings by Almagro et al. (2017) and
Yang et al. (2016).

Observed crop yields and above ground biomass did not show significant differences among treatments $(p>0.05)$. As shown in Fig. 2a, the mean simulated yields among the four treatments were $9548 \mathrm{~kg} / \mathrm{ha}$ in $2011,9806 \mathrm{~kg} / \mathrm{ha}$ in 2012, $10299 \mathrm{~kg} / \mathrm{ha}$ in 2013, and $8903 \mathrm{~kg} / \mathrm{ha}$ in 2014, respectively. The RE values between the observed and simulated yields were in the range of $-22.8-27.7 \%$ (Mean: $11.4 \%$ ). The mean above ground biomass among the four treatments were $20204 \mathrm{~kg} / \mathrm{ha}$ in 2011, $21736 \mathrm{~kg} / \mathrm{ha}$ in 2012, $20376 \mathrm{~kg} / \mathrm{ha}$ in 2013, and $18551 \mathrm{~kg} / \mathrm{ha}$ in 2014 with a mean $\mathrm{RE}$ value $=8.8 \%$, respectively (Fig. 2b). These simulated results indicated that stover and tillage practices did not significantly influence the crop yields and above ground biomass.

\section{2. $\mathrm{CO}_{2}$ and $\mathrm{N}_{2} \mathrm{O}$ emissions}

The daily observed and simulated $\mathrm{CO}_{2}$ and $\mathrm{N}_{2} \mathrm{O}$ emissions are shown in Fig. 3, with statistics listed in Table 2. The model satisfactorily predicted $\mathrm{CO}_{2}$ emissions with a PBIAS within $\pm 7 \%$, with NSE $>0.53$, 

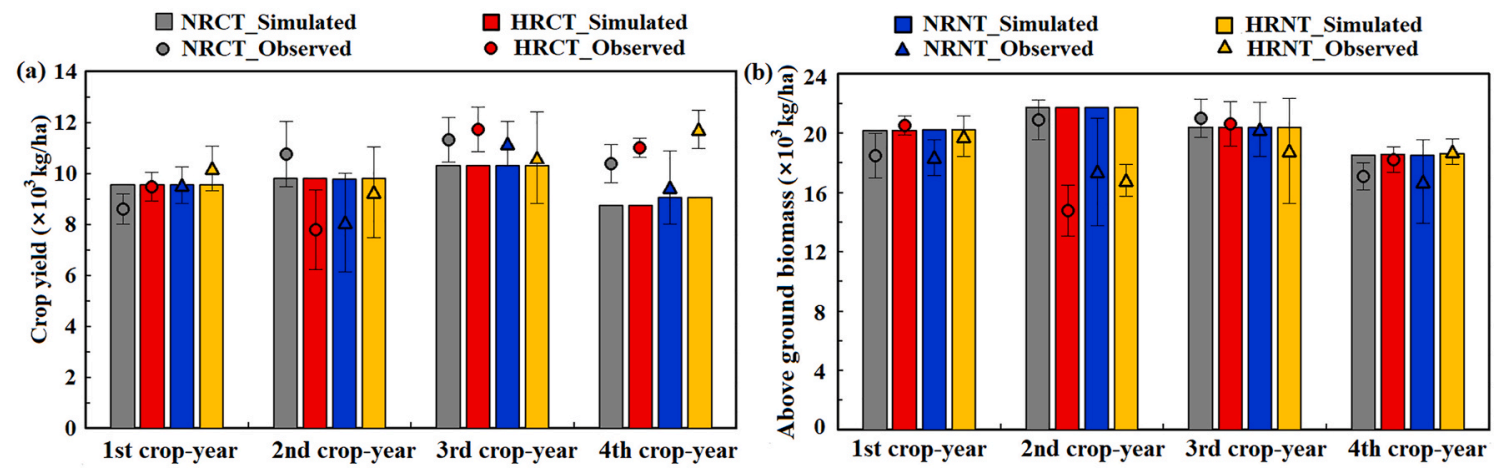

Fig. 2. RZWQM2-simulated and observed crop yields ( $\mathrm{kg} / \mathrm{ha}$ ) and above ground biomass (kg/ha) in each treatment (i.e., NRCT, HRCT, NRNT, and HRNT) over the four crop-years. The notations used here are same as those in Fig. 1.

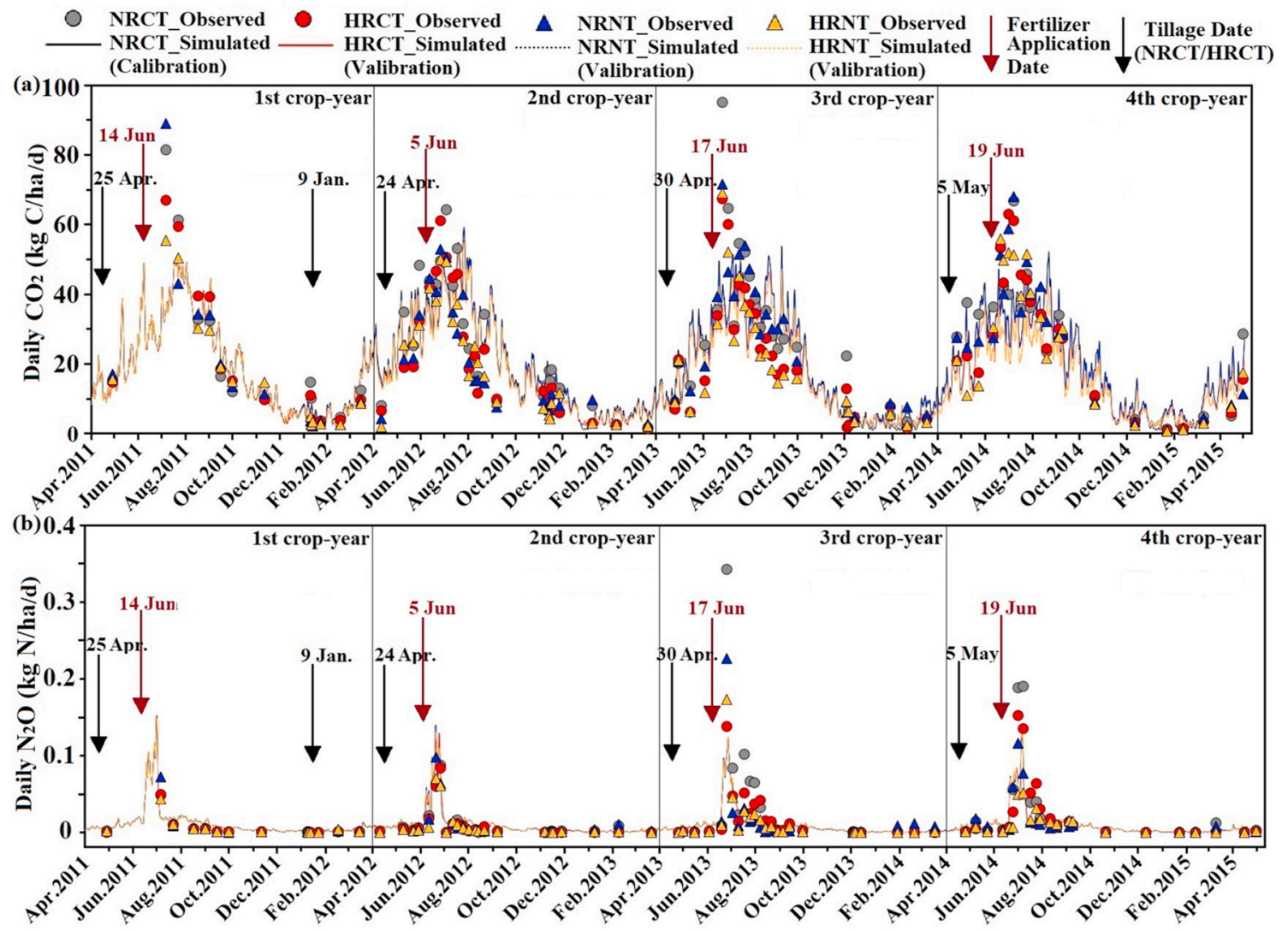

Fig. 3. Observed and RZWQM2-simulated $\mathrm{CO}_{2}(\mathrm{~kg} \mathrm{C} / \mathrm{ha} / \mathrm{d})$ and $\mathrm{N}_{2} \mathrm{O}(\mathrm{kg} \mathrm{N} / \mathrm{ha} / \mathrm{d})$ emissions in the calibration (NRCT treatment) and validation phases (HRCT, NRNT, and HRNT treatments). The arrows indicate the fertilizer application and the tillage practices. The notations used here are same as those in Fig. 1.

IoA $>0.83$, and $\mathrm{R}^{2}>0.73$, respectively. As shown in Table 2 , the $\mathrm{CO}_{2}$ emissions were strongly correlated to ST with the Pearson correlation coefficients $(r)$ of $0.74 \pm 0.01$ between $\mathrm{Ob}_{\mathrm{ST}}$ and $\mathrm{Ob}_{\mathrm{CO} 2}$ and $0.94 \pm 0.01$ between $\mathrm{Sim}_{\mathrm{ST}}$ and $\mathrm{Sim}_{\mathrm{CO} 2}$ in all the management treatments. In fact, peaks of soil $\mathrm{CO}_{2}$ emissions occurred at the annual maximum temperatures (in late July or early August), since they were related to high ST and microbial activities (Liang et al., 2016; Yang et al., 2020a, 2020b). However, the $\mathrm{N}_{2} \mathrm{O}$ emissions were correlated to both VWC and ST.

It was found that both stover and tillage managements tend to increase observed and simulated $\mathrm{CO}_{2}$ emissions. Between the NR and $\mathrm{HR}$ treatments under the same tillage management, the observed and simulated average $\mathrm{CO}_{2}$ emissions $\left(\mathrm{Ob}_{\mathrm{CO} 2}\right.$ and $\left.\mathrm{Sim}_{\mathrm{CO} 2}\right)$ in the NRCT treatment were $12.5 \%$ and $10.4 \%$ higher, respectively, than those in the HRCT treatment; and $\mathrm{Ob}_{\mathrm{CO} 2}$ and $\mathrm{Sim}_{\mathrm{CO} 2}$ in the NRNT were $12.0 \%$ and
9.5\% higher, respectively, than those in the HRNT treatment $(p<0.01)$. The higher $\mathrm{CO}_{2}$ emissions in the NR treatments were attributed to increased $\mathrm{C}$ and $\mathrm{N}$ inputs into the soil (Fig. S3, supplementary information) and to microclimatic differences associated with changes in the soil cover (Fig. S4, supplementary information) (Jin et al., 2014). The average simulated SOC across four years were $182 \mathrm{Mg} \mathrm{C} /$ ha in NRCT and $184 \mathrm{Mg} \mathrm{C} / \mathrm{ha}$ in NRNT, which were higher than HRCT (179 Mg C/ha) and HRNT (178 Mg C/ha). Between the CT and NT treatments under the same stover management, the $\mathrm{Ob}_{\mathrm{CO} 2}$ and $\mathrm{Sim}_{\mathrm{CO} 2}$ in the NRCT treatment were $8.2 \%$ and $1.4 \%$ higher, respectively, than those in the NRNT treatment; and $\mathrm{Ob}_{\mathrm{CO} 2}$ and $\mathrm{Sim}_{\mathrm{CO} 2}$ in the HRCT treatment were $7.6 \%$ and $0.5 \%$ higher, respectively, than those in the HRNT treatment. Moreover, it can be seen that the differences among treatments increases gradually with year, especially the 3rd and 4th crop-year (Figs. 3a and 4a), which 
Table 2

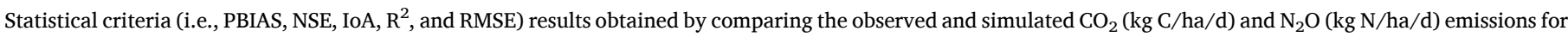
each treatment.

\begin{tabular}{|c|c|c|c|c|c|c|c|c|c|c|c|c|}
\hline \multirow[t]{2}{*}{ Treatments } & \multicolumn{6}{|c|}{$\mathrm{CO}_{2}$ emission } & \multicolumn{6}{|c|}{$\mathrm{N}_{2} \mathrm{O}$ emission } \\
\hline & $\mathrm{Ob}_{\mathrm{CO} 2}$ & $\mathrm{Sim}_{\mathrm{CO} 2}$ & PBIAS & NSE & IoA & $\mathrm{R}^{2}$ & $\mathrm{Ob}_{\mathrm{N} 2 \mathrm{O}}$ & $\mathrm{Sim}_{\mathrm{N} 2 \mathrm{O}}$ & PBIAS & NSE & IoA & $\mathrm{R}^{2}$ \\
\hline NRCT & 26.80 & 25.00 & $6.7 \%$ & 0.59 & 0.85 & 0.77 & 0.020 & 0.017 & $20.2 \%$ & 0.55 & 0.82 & 0.75 \\
\hline HRCT & 23.45 & 22.41 & $4.4 \%$ & 0.57 & 0.84 & 0.76 & 0.015 & 0.016 & $-4.1 \%$ & 0.61 & 0.87 & 0.78 \\
\hline NRNT & 24.61 & 24.65 & $-0.2 \%$ & 0.61 & 0.86 & 0.73 & 0.013 & 0.016 & $-17.5 \%$ & 0.60 & 0.86 & 0.78 \\
\hline HRNT & 21.66 & 22.30 & $-2.9 \%$ & 0.53 & 0.83 & 0.78 & 0.010 & 0.016 & $-28.6 \%$ & 0.43 & 0.85 & 0.76 \\
\hline \multirow[t]{2}{*}{ Treatments } & \multicolumn{12}{|l|}{$r$ value } \\
\hline & $\begin{array}{l}\mathrm{Ob}_{\mathrm{VwC}} \text { and } \\
\mathrm{Ob}_{\mathrm{CO} 2}\end{array}$ & $\begin{array}{l}\mathrm{Ob}_{\mathrm{ST}} \text { and } \\
\mathrm{Ob}_{\mathrm{CO} 2}\end{array}$ & \multicolumn{2}{|c|}{$\begin{array}{l}\operatorname{Sim}_{\mathrm{VWC}} \text { and } \\
\operatorname{Sim}_{\mathrm{CO} 2}\end{array}$} & \multicolumn{2}{|l|}{$\begin{array}{l}\operatorname{Sim}_{\mathrm{ST}} \text { and } \\
\operatorname{Sim}_{\mathrm{CO} 2}\end{array}$} & $\begin{array}{l}\mathrm{Ob}_{\mathrm{VwC}} \text { and } \\
\mathrm{Ob}_{\mathrm{N} 2 \mathrm{O}}\end{array}$ & $\begin{array}{l}\mathrm{Ob}_{\mathrm{ST}} \text { and } \\
\mathrm{Ob}_{\mathrm{N} 2 \mathrm{O}}\end{array}$ & \multicolumn{2}{|c|}{$\begin{array}{l}\operatorname{Sim}_{\mathrm{VWC}} \text { and } \\
\operatorname{Sim}_{\mathrm{N} 2 \mathrm{O}}\end{array}$} & \multicolumn{2}{|l|}{$\begin{array}{l}\operatorname{Sim}_{\mathrm{ST}} \text { and } \\
\operatorname{Sim}_{\mathrm{N} 2 \mathrm{O}}\end{array}$} \\
\hline NRCT & $0.42 * *$ & $0.75^{* *}$ & \multicolumn{2}{|c|}{ / } & \multicolumn{2}{|l|}{$0.95^{* *}$} & $0.43^{* *}$ & $0.33^{* *}$ & \multicolumn{2}{|c|}{$0.26^{*}$} & \multicolumn{2}{|l|}{$0.45^{* *}$} \\
\hline HRCT & $0.38^{* *}$ & $0.74 * *$ & \multicolumn{2}{|c|}{$0.23 *$} & \multicolumn{2}{|l|}{$0.94 * *$} & $0.42^{* *}$ & $0.38 * *$ & \multicolumn{2}{|c|}{0.31 ** } & \multicolumn{2}{|l|}{$0.45^{* *}$} \\
\hline NRNT & $0.41^{* *}$ & $0.75^{* *}$ & \multicolumn{2}{|c|}{ / } & \multicolumn{2}{|l|}{$0.95^{* * *}$} & $0.30 * *$ & $0.31^{* *}$ & \multicolumn{2}{|c|}{$0.26^{*}$} & \multicolumn{2}{|l|}{$0.44 * *$} \\
\hline HRNT & $0.39 * *$ & $0.74 * *$ & \multicolumn{2}{|c|}{$0.28^{*}$} & \multicolumn{2}{|l|}{$0.94 * *$} & $0.33^{* *}$ & $0.35 * *$ & \multicolumn{2}{|c|}{$0.31 * *$} & \multicolumn{2}{|l|}{$0.44 * *$} \\
\hline
\end{tabular}

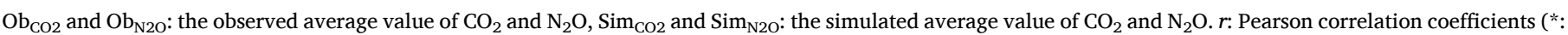
$\mathrm{p}<0.05,{ }^{* *}: p<0.01$ and $/: p>0.05$ ). The notations used here are same as those in Fig. 1 .
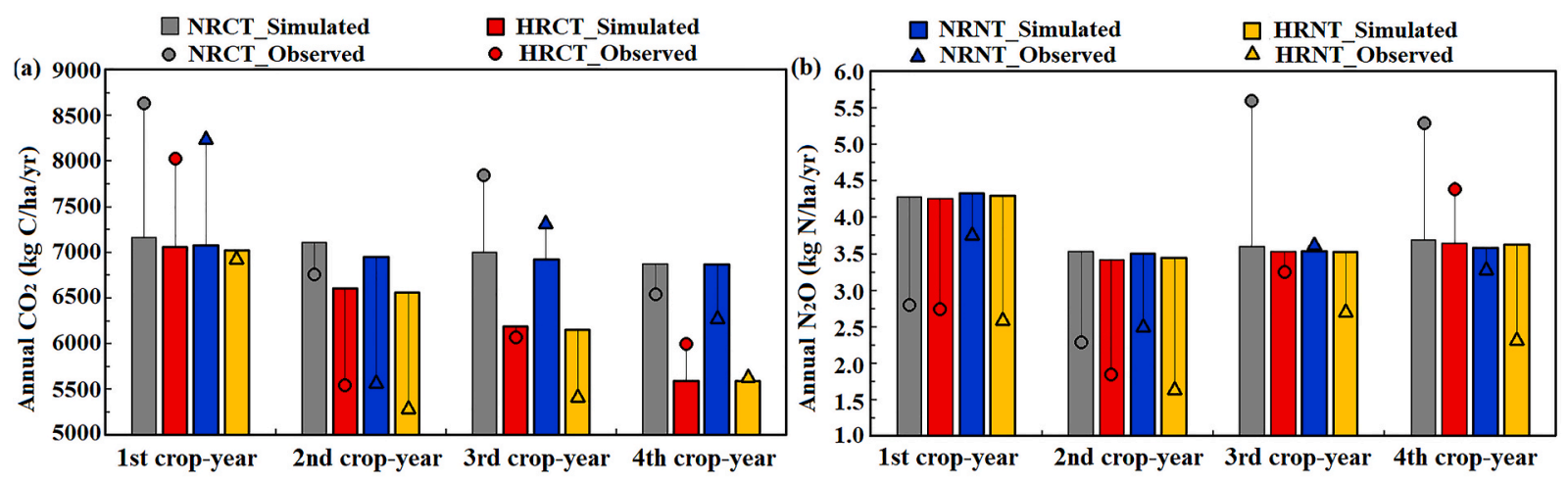

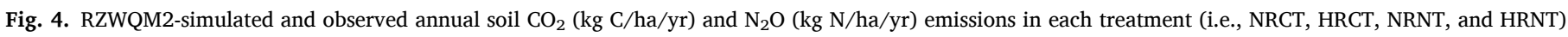
over the four crop-years. The notations used here are same as those in Fig. 1.

suggested that a cumulative effect of stover and tillage managements existed and that long-term effects should be evaluated in addition to short-term effects. Among the four treatments, the NRCT treatment had the highest annual $\mathrm{CO}_{2}$ emissions with an average of $7555 \mathrm{~kg} \mathrm{C} / \mathrm{ha} / \mathrm{yr}$ for observation and $7034 \mathrm{~kg} \mathrm{C} / \mathrm{ha} / \mathrm{yr}$ for simulation, respectively, and the annual $\mathrm{CO}_{2}$ emissions for simulation were followed by NRNT (6952 $\mathrm{kg} \mathrm{C} / \mathrm{ha} / \mathrm{yr}$ ), HRCT (6360 kg C/ha/yr) and HRNT (6329 kg C/ha/yr) (Fig. 4a). The RE values between the observed and simulated annual $\mathrm{CO}_{2}$ emissions were in the range of $-23.8-22.3 \%$.

Based on the statistics of IoA $(0.85 \pm 0.03), R^{2}(0.77 \pm 0.02)$, and NSE $(0.55 \pm 0.12)$ values (Table 2$)$, the model performed well in simulating $\mathrm{N}_{2} \mathrm{O}$ emissions. Nitrification was the main $\mathrm{N}_{2} \mathrm{O}$-producing process, which accounted for more than $99 \%$ of the total $\mathrm{N}_{2} \mathrm{O}$ emissions as simulated in the verified model. It was due to the unsaturated soil VWC (simulated: $0.18-0.27 \mathrm{~cm}^{3} / \mathrm{cm}^{3}$; observed: $0.13-0.31 \mathrm{~cm}^{3} / \mathrm{cm}^{3}$ (Fig. 1a) which favored the nitrification process (Sanz-Cobena et al., 2017). The observed and simulated $\mathrm{N}_{2} \mathrm{O}$ emissions for all treatments increased rapidly following urea applications (Fig. 3b), due to high nitrification rate during the urea transformation. In addition, the peak time of $\mathrm{N}_{2} \mathrm{O}$ emissions in all treatments (i.e., within 20 days following the urea application) was accurately predicted, although some peak values were underestimated, especially in 2013 and 2014.

Although $\mathrm{N}_{2} \mathrm{O}$ emissions are lower than $\mathrm{CO}_{2}$ emissions in the experimental fields, it also has 298 times the global warming potential than $\mathrm{CO}_{2}$ (100-year horizon) (Forster et al., 2007). When averaged observation across all years, NR and CT practices brought about a slightly higher $\mathrm{N}_{2} \mathrm{O}$ emissions. The observed average $\mathrm{N}_{2} \mathrm{O}$ emissions across the four years $\left(\mathrm{Ob}_{\mathrm{N} 2 \mathrm{O}}\right)$ were $0.020,0.015,0.013$, and $0.010 \mathrm{~kg}$
$\mathrm{N} /$ ha/d in the NRCT, HRCT, NRNT, and HRNT treatments, respectively. Similar tendencies were found among the simulation results $(p<0.01)$, however, the differences in simulated $\mathrm{N}_{2} \mathrm{O}$ emissions $\left(\mathrm{Sim}_{\mathrm{N} 2 \mathrm{O}}\right.$ ) between the treatments were small, the simulated average value of $\operatorname{Sim}_{\mathrm{N} 2 \mathrm{O}}$ were $\sim 0.016 \pm 0.001 \mathrm{~kg} \mathrm{~N} / \mathrm{ha}$ (Table 2) across all treatments and years. The results may be explained by the fact that VWC and ST are the key factors for $\mathrm{N}_{2} \mathrm{O}$ emissions (Sanz-Cobena et al., 2017) and the simulated differences in VWC and ST among the treatments were small during the growing season (Fig. 1). Moreover, the NRCT treatment also had the highest $\mathrm{N}_{2} \mathrm{O}$ emissions with an annual average of $4.0 \mathrm{~kg} \mathrm{~N} / \mathrm{ha} / \mathrm{yr}$ for observation and $3.8 \mathrm{~kg} \mathrm{~N} / \mathrm{ha} / \mathrm{yr}$ for simulation, respectively. The least $\mathrm{N}_{2} \mathrm{O}$ emissions were simulated in HRNT with an annual average of 3.7 $\mathrm{kg} \mathrm{N} / \mathrm{ha} / \mathrm{yr}$. The RE values between the observed and simulated annual $\mathrm{N}_{2} \mathrm{O}$ emissions were relatively larger than the RE of annual $\mathrm{N}_{2} \mathrm{O}$ emissions, which were in the range of $-55.3-52.3 \%$ (Fig. 4b). This was due to the underestimated $\mathrm{N}_{2} \mathrm{O}$ peaks in simulation results and boundary error of trapezoidal integration method in observation. The observed boundary error during the non-growing seasons, which obeys first-order algebraic accuracy, might be large due to the large step size ( $\sim 30$ days). Nevertheless, the predicted daily $\mathrm{CO}_{2}$ and $\mathrm{N}_{2} \mathrm{O}$ emissions were better than previous studies obtained using the RZWQM2 or other models (Abdalla et al., 2020; Gillette et al., 2017; Jiang et al., 2019; Taft et al., 2019).

\subsection{Long-term impacts of stover and tillage practices on annual $\mathrm{CO}_{2}$ emissions}

Long-term simulations using historical weather and agronomic 
management practices from 2001 to 2015 indicated that the NRCT treatment showed the highest annual $\mathrm{CO}_{2}$ emissions $\left(E_{\mathrm{CO}_{2}}\right)$, followed by NRNT, HRCT and HRNT (Fig. 5a). It was due to the highest soil microbial biomass in NRCT, as shown in Fig. S5 (Supplementary information). Meanwhile, a general decrease in the annual $\mathrm{CO}_{2}$ emissions $\left(E_{\mathrm{CO}_{2}}\right)$ over the simulation period (Fig. 5a). The $E_{\mathrm{CO}_{2}}$ decreased from $6760 \pm 253 \mathrm{~kg}$ C/ha (Mean \pm SD) in 2000-5122, 3563, 2628, and $1864 \mathrm{~kg} \mathrm{C} /$ ha in 2015 in the NRCT, NRNT, HRCT, and HRNT treatments, respectively. It was due to a slow decrease in SOC in this long-term model (Fig. S6, supplementary information), which was the similar result to Jin et al. (2017). The simulated SOC changes ( $\triangle$ SOC) from 2001 to 2015 were $-24 \%$ in NRCT, $-29 \%$ in NRNT, $-30 \%$ in HRCT and $-32 \%$ in HRNT, respectively. Among the treatments, the variation proportion of $E_{\mathrm{CO}_{2}}$ comparing to HRNT $\left(V_{\mathrm{CO}_{2}}\right)$ were $7.8 \%$ for NRCT $(S R D=0 \%)$ and $7.7 \%$ for HRCT $(S R D=100 \%)$ in 2001 over HRNT, respectively; then $V_{\mathrm{CO}_{2}}$ increased to $63.6 \%$ for NRCT $(S R D=0 \%$ ) and $29.1 \%$ for HRCT $(S R D=$ $100 \%$ ) over HRNT in 2015, respectively. This was be due to cumulative effect of stover returned into the soil as the source for $\mathrm{C}$ and $\mathrm{N}$ in the soil nutrient cycle and the residue degrading on the soil surface at a low rate (Schmer et al., 2014). Tillage practices may also have the cumulative effect on $\mathrm{CO}_{2}$ emissions, and the $\mathrm{VP}_{\mathrm{CO}_{2}}$ of the CT treatments were always higher than that of the NT treatments when considering the same $S R D$ due to mixing of residue into the soil. In 2001, the $\mathrm{VP}_{\mathrm{CO}_{2}}$ of the NRCT $(S R D=0 \%)$ and NRNT $(S R D=0 \%)$ treatments were $7.8 \%$ and $0.0 \%$ higher than those of the HRNT, respectively. By 2015, these differences increased to $63.6 \%$ for NRCT $(S R D=0 \%$ ) and $47.7 \%$ for NRNT ( $S R D=$ $0 \%)$, respectively.

To further analyze the cumulative effects of stover and tillage practices, a MLR analysis was developed by using the data showed in Fig. 5 a and S7a (Supplementary information) and considering 6 factors (i.e., $Y$, $S R D, T, \overline{V W C}, \overline{S T}$ and $F)$ :

$$
\begin{aligned}
& E_{\mathrm{CO}_{2}}= \\
& \quad-0.25 \cdot Y+1.41 \cdot S R D+0.42 \cdot T-19.18 \cdot \overline{V W C}+0.18 \cdot \overline{S T}-0.016 \cdot F \\
& \quad+11.89
\end{aligned}
$$

$$
V P_{\mathrm{CO}_{2}}=0.019 \cdot Y+0.238 \cdot S R D+0.029 \cdot T+2.43 \cdot \overline{V W C}-0.717
$$

where $E_{\mathrm{CO}_{2}}$ represents the annual $\mathrm{CO}_{2}$ emissions ( $\times 10^{3} \mathrm{~kg} \mathrm{C} / \mathrm{ha}$ ), $V P_{\mathrm{CO}_{2}}$ (\%) the variation proportion of $E_{\mathrm{CO}_{2}}$ under different $S R D$ comparing to HRNT, $Y$ the cumulative years, $S R D$ the stover removal degree (which varied between 0 and 100\%), $T$ the tillage practices (no-till $=0$; tillage $=1), \overline{V W C}$ the annual average VWC $\left(\mathrm{cm}^{3} / \mathrm{cm}^{3}\right), \overline{S T}$ the annual average ST $\left({ }^{\circ} \mathrm{C}\right)$, and $F$ the fertilizer application rate $(\mathrm{kg} \mathrm{N} / \mathrm{ha})$.

According to the acceptable standard $\left(R_{a d j}^{2}>0.5\right)$, the MLR analysis showed good statistical results with $R_{a d j}^{2}=0.92$ for $E_{\mathrm{CO}_{2}}, R_{a d j}^{2}=0.78$ for $V P_{\mathrm{CO}_{2}}$. All six variables were closely correlated with $E_{\mathrm{CO}_{2}}$ (Eq. (5)). These results also suggested that a high simulation accuracy of the VWC and ST values was a prerequisite for the prediction of $\mathrm{CO}_{2}$ emissions. The 15year average of $\overline{V W C}$ were $0.240,0.245,0.229$ and $0.235 \mathrm{~cm}^{3} / \mathrm{cm} 3$ in the NRCT, NRNT, HRCT, and HRNT treatments, and the 15-year average of $\overline{S T}$ in each treatment were $0.96 \pm 0.01{ }^{\circ} \mathrm{C}$. The $V P_{\mathrm{CO}_{2}}$ was only statistically significant in relation to $Y, S R D, T$, and $\overline{V W C}$ (Eq. (6)). The $F$ and $\overline{S T}$ were not statistically significant with $\mathrm{VP}_{\mathrm{CO}_{2}}$. Because $F$ was the same in all treatments, and the ST differences among the treatments were also small. Notably, $Y$ was strongly influenced by both $E_{\mathrm{CO}_{2}}$ and $V \mathrm{CO}_{2}$, indicating significant cumulative effects of the stover removal, tillage and their interaction.

\subsection{Long-term impacts of stover and tillage practices on annual $\mathrm{N}_{2} \mathrm{O}$ emissions}

The simulated average value of annual $\mathrm{N}_{2} \mathrm{O}$ emissions across the four treatments fluctuated from $3.8 \mathrm{~kg} \mathrm{~N} /$ ha to $1.9 \mathrm{~kg} \mathrm{~N} / \mathrm{ha}$ (Fig. 5b). Longterm stover retention and CT managements slightly stimulated high soil $\mathrm{N}_{2} \mathrm{O}$ emissions. Due to the non-linear relationship of $V P_{N_{2} O}$, the interaction term $T \cdot S R D$ was additionally considered in the MLR analysis besides the six factors considered in $\mathrm{CO}_{2}$ emissions. The $\mathrm{N}_{2} \mathrm{O}$ emissions were described by the following equations according to the data contained in Fig. 5b and S7b (Supplementary information):

$$
\begin{aligned}
& E_{N_{2} O}=-0.09 \cdot Y+0.09 \cdot S R D-0.11 \cdot T+0.08 \cdot F+24.58 \cdot \overline{V W C}+0.08 \cdot \overline{S T} \\
& \quad-4.72
\end{aligned}
$$

$V P_{N_{2} O}=0.025 \cdot T+0.057 \cdot T \cdot S R D-0.008 \cdot \overline{S T}+0.094$

where $E_{\mathrm{N}_{2} \mathrm{O}}$ represents the annual $\mathrm{N}_{2} \mathrm{O}$ emissions (kg N/ha), and $V P_{\mathrm{N}_{2} \mathrm{O}}$ (\%) the variation proportion of $E_{\mathrm{N}_{2} \mathrm{O}}$ under different $S R D s$ comparing to HRNT.

The $R_{a d j}^{2}$ values obtained for $E_{\mathrm{N}_{2} \mathrm{O}}$ and $V P_{\mathrm{N}_{2} \mathrm{O}}$ were 0.85 and 0.50 , respectively, and demonstrated adequate goodness-of-fit. $E_{\mathrm{N}_{2} \mathrm{O}}$ was well correlated with all six factors (Eq. (7)), which was similar with $E_{\mathrm{CO}_{2}}$. $V P_{N_{2} \mathrm{O}}$ was highly correlated with $S R D, T$, and $\overline{S T}$, and was uncorrelated with $Y, F$ and $\overline{V W C}$ (Eq. (8)). The absence of $Y$ indicated there was no cumulative effects on $\mathrm{N}_{2} \mathrm{O}$ emissions. It can be explained by relatively fast nitrification rate in the verified model (Table S5, supplementary information), and the $\mathrm{N}_{2} \mathrm{O}$ emissions from nitrification was accounted for $99 \%$ of the total simulated emissions.

\section{Conclusions}

Conservation management practices (i.e., stover retention and notill) are being widely used in croplands around the world. However, the effects of such practices on $\mathrm{CO}_{2}$ and $\mathrm{N}_{2} \mathrm{O}$ emissions have not been

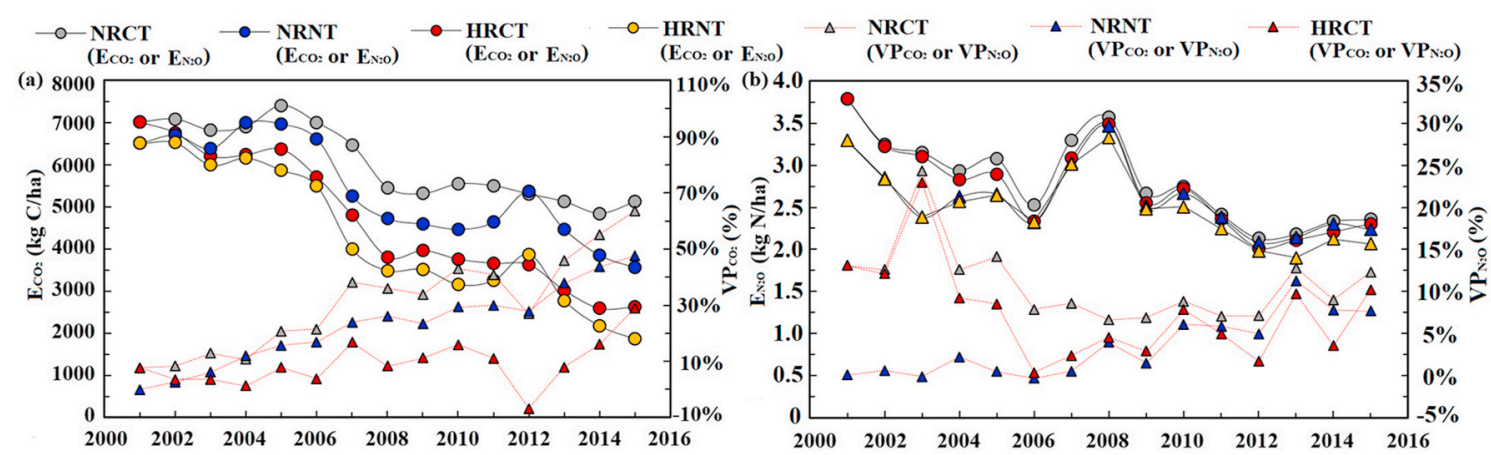

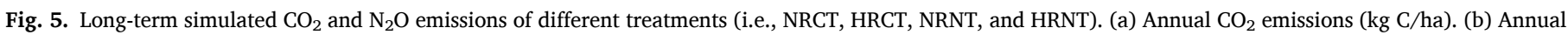
$\mathrm{N}_{2} \mathrm{O}$ emissions (kg N/ha). The notations used here are same as those in Fig. 1. 
clearly established and predicted. In this work, effects of conservation practices on $\mathrm{CO}_{2}$ and $\mathrm{N}_{2} \mathrm{O}$ emissions were accurately simulated by using a calibrated and validated RZWQM2 model. Residue retention and tillage practices were found to increase $\mathrm{CO}_{2}$ and $\mathrm{N}_{2} \mathrm{O}$ emissions; meanwhile, the largest and least GHG emissions were simulated in the NRCT and HRNT. The long-term simulation suggested that annual $\mathrm{CO}_{2}$ and $\mathrm{N}_{2} \mathrm{O}$ emissions would respond linearly to $Y, S R D, T, \overline{S W C}, \overline{S T}$ and $F$. Stover and tillage practices had cumulative effects on $\mathrm{CO}_{2}$ emissions, but not that of $\mathrm{N}_{2} \mathrm{O}$ emissions. In conclusion, this work provides a base for the development of guidelines for conservation practices and for the prediction of $\mathrm{CO}_{2}$ and $\mathrm{N}_{2} \mathrm{O}$ emissions.

\section{CRediT author statement}

Haomiao Cheng: Conceptualization, Methodology, Writing - original draft, Kexin Shu: Writing- Reviewing and Editing, Zhiming Qi: Conceptualization, Supervision, Reviewing and Editing, Liwang Ma: Software, Validation, Reviewing and Editing, Virginia L. Jin: Field experiments, Reviewing and Editing, Youjia Li: Software, Validation. Marty R. Schmer: Field experiments, Reviewing and Editing. Brian J. Wienhold: Field experiments, Reviewing and Editing. Shaoyuan Feng: Reviewing and Editing.

\section{Declaration of competing interest}

The authors declare no conflict of interest.

\section{Acknowledgements}

This study was conducted during a visit to McGill University. This visit was supported by the National Natural Science Foundation of China (Grant No. 51809226), the China Postdoctoral Science Foundation funded project (Grant No. 2018M632390), the Natural Science Foundation of the Jiangsu Higher Education Institutions of China (Grant No. 18KJB610022).

\section{Appendix A. Supplementary data}

Supplementary data to this article can be found online at https://doi. org/10.1016/j.jenvman.2021.112097.

\section{References}

Abbas, F., Hammad, H.M., Ishaq, W., Farooque, A.A., Bakhat, H.F., Zia, Z., Fahad, S., Farhad, W., Cerda, A., 2020. A review of soil carbon dynamics resulting from agricultural practices. J. Environ. Manag. 268, 110319.

Abdalla, M., Hastings, A., Cheng, K., Yue, Q., Chadwick, D., Espenberg, M., Truu, J., Rees, R.M., Smith, P., 2019. A critical review of the impacts of cover crops on nitrogen leaching, net greenhouse gas balance and crop productivity. Global Change Biol. 25, 2530-2543.

Abdalla, M., Song, X., Ju, X., Topp, C.F.E., Smith, P., 2020. Calibration and validation of the DNDC model to estimate nitrous oxide emissions and crop productivity for a summer maize-winter wheat double cropping system in Hebei, China. Environ. Pollut. 262, 114199.

Ahuja, L.R., Rojas, K.W., Hanson, J.D., Shaffer, M.J., Ma, L., 2000. Root Zone Water Quality Model: Modelling Management Effects on Water Quality and Crop Production. Water Resources Publications, Highlands Ranch, Colorado.

Almagro, M., Garcia-Franco, N., Martinez-Mena, M., 2017. The potential of reducing tillage frequency and incorporating plant residues as a strategy for climate change mitigation in semiarid Mediterranean agroecosystems. Agric. Ecosyst. Environ. 246, 210-220.

Cameira, M.R., Fernando, R.M., Ahuja, L.R., Ma, L., 2007. Using RZWQM to simulate the fate of nitrogen in field soil-crop environment in the Mediterranean region. Agric. Water Manag. 90, 121-136.

Chen, X., Qi, Z., Gui, D., Gu, Z., Ma, L., Zeng, F., Li, L., 2019. Simulating impacts of climate change on cotton yield and water requirement using RZWQM2. Agric. Water Manag. 222, 231-241.

De Stefano, A., Jacobson, M.G., 2018. Soil carbon sequestration in agroforestry systems: a meta-analysis. Agrofor. Syst. 92, 285-299.

Dendooven, L., Patino-Zuniga, L., Verhulst, N., Luna-Guido, M., Marsch, R., Govaerts, B., 2012. Global warming potential of agricultural systems with contrasting tillage and residue management in the central highlands of Mexico. Agric. Ecosyst. Environ. $152,50-58$.
Ding, J., Hu, W., Wu, J., Yang, Y., Feng, H., 2020. Simulating the effects of conventional versus conservation tillage on soil water, nitrogen dynamics, and yield of winter wheat with RZWQM2. Agric. Water Manag. 230, 105956.

Fan, J.L., Luo, R.Y., Liu, D.Y., Chen, Z.M., Luo, J.F., Boland, N., Tang, J.W., Hao, M.D., McConkey, B., Ding, W.X., 2018. Stover retention rather than no-till decreases the global warming potential of rainfed continuous maize cropland. Field Crop. Res. 219, 14-23.

Fang, Q.X., Ma, L., Halvorson, A.D., Malone, R.W., Ahuja, L.R., Del Grosso, S.J., Hatfield, J.L., 2015. Evaluating four nitrous oxide emission algorithms in response to $\mathrm{N}$ rate on an irrigated corn field. Environ. Model. Software 72, 56-70.

Follett, R.F., Jantalia, C.P., Halvorson, A.D., 2013. Soil carbon dynamics for irrigated corn under two tillage systems. Soil Sci. Soc. Am. J. 77, 951-963.

Forster, P., Ramaswamy, V., Artaxo, P., Berntsen, T., Dorland, R.V., 2007. Changes in Atmospheric Constituents and in Radiative Forcing. The Physical Science Basis. Cambridge University Press, Cambrige, UK.

Gillette, K., Ma, L.W., Malone, R.W., Fang, Q.X., Halvorson, A.D., Hatfield, J.L., Ahuja, L. R., 2017. Simulating N2O emissions under different tillage corn using RZ-SHAW model systems of irrigated. Soil Till. Res. 165, 268-278.

Gillette, K., Malone, R.W., Kaspar, T.C., Ma, L., Parkin, T.B., Jaynes, D.B., Fang, Q.X., Hatfield, J.L., Feyereisen, G.W., Kersebaum, K.C., 2018. N loss to drain flow and N2O emissions from a corn-soybean rotation with winter rye. Sci. Total Environ. 618, 982-997.

Hanson, J.D., Rojas, K.W., Shaffer, M.J., 1999. Calibrating the root Zone water quality model. Agron. J. 91, 171-177.

Hu, L., Wang, L.G., Li, J.Z., Gao, M.F., Zhang, J., Zhang, J.F., Qiu, J.J., Deng, J., Li, C.S., Frolking, S., 2017. The development of China-DNDC and review of its applications for sustaining Chinese agriculture. Ecol. Model. 348, 1-13.

IPCC, 2007. Climate Change 2007. Working Group I: the Physical Science Basis. Intergovernmental Panel on Climate Change, Geneva, Switzerland.

Jiang, Q.J., Qi, Z.M., Madramootoo, C.A., Creze, C., 2019. Mitigating greenhouse gas emissions in subsurface-drained field using RZWQM2. Sci. Total Environ. 646, 377-389.

Jin, V.L., Baker, J.M., Johnson, J.M.F., Karlen, D.L., Lehman, R.M., Osborne, S.L., Sauer, T.J., Stott, D.E., Varvel, G.E., Venterea, R.T., Schmer, M.R., Wienhold, B.J., 2014. Soil greenhouse gas emissions in response to corn stover removal and tillage management across the US corn belt. Bioenerg. Res. 7, 517-527.

Jin, V.L., Schmer, M.R., Stewart, C.E., Sindelar, A.J., Varvel, G.E., Wienhold, B.J., 2017. Long-term no-till and stover retention each decrease the global warming potential of irrigated continuous corn. Global Change Biol. 23, 2848-2862.

Kumara, T.M.K., Kandpal, A., Pal, S., 2020. A meta-analysis of economic and environmental benefits of conservation agriculture in South Asia. J. Environ. Manag. 269, 110773.

Lee, J.H., Lee, J.G., Jeong, S.T., Gwon, H.S., Kim, P.J., Kim, G.W., 2020. Straw recycling in rice paddy: trade-off between greenhouse gas emission and soil carbon stock increase. Soil Till. Res. 199.

Liang, L.L., Grantz, D.A., Jenerette, G.D., 2016. Multivariate regulation of soil CO2 and N2O pulse emissions from agricultural soils. Global Change Biol. 22, 1286-1298.

Locker, C.R., Torkamani, S., Laurenzi, I.J., Jin, V.L., Schmer, M.R., Karlen, D.L., 2019 Field-to-farm gate greenhouse gas emissions from corn stover production in the Midwestern US. J. Clean. Prod. 226, 1116-1127.

Ma, L., Shaffer, M.J., Boyd, J.K., Waskom, R., Ahuja, L.R., Rojas, K.W., Xu, C., 1998. Manure management in an irrigated silage corn field: experiment and modeling. Soil Sci. Soc. Am. J. 62, 1006-1017.

Ma, L., Ahuja, L.R., Ascough, J.C., Shaffer, M.J., Rojas, K.W., Malone, R.W., Cameira, M. R., 2000. Integrating system modeling with field research in agriculture: applications of the Root Zone Water Quality Model (RZWQM). Adv. Agron. 71, 233-292.

Ma, L., Hoogenboom, G., Ahuja, L.R., Ascough, J.C., Saseendran, S.A., 2006. Evaluation of the RZWQM-CERES-maize hybrid model for maize production. Agric. Syst. 87, 274-295.

Ma, L., Ahuja, L.R., Nolan, B.T., Malone, R.W., Trout, T.J., Qi, Z., 2012. Root Zone water quality model (RZWQM2): model use, calibration, and validation. Trans. ASABE (Am. Soc. Agric. Biol. Eng.) 55, 1425-1446.

Ma, Y.C., Liu, D.L., Schwenke, G., Yang, B., 2019. The global warming potential of strawreturn can be reduced by application of straw-decomposing microbial inoculants and biochar in rice-wheat production systems. Environ. Pollut. 252, 835-845.

Nash, J.E., Sutcliffe, J.V., 1970. River flow forecasting through conceptual models part I - a discussion of principles. J. Hydrol. 10, 282-290.

Oertel, C., Matschullat, J., Zurba, K., Zimmermann, F., Erasmi, S., 2016. Greenhouse gas emissions from soils A review. Chem. Erde-Geochem. 76, 327-352.

Pachauri, R.K., Allen, M.R., Barros, V.R., Broome, J., Cramer, W., Christ, R., Church, J.A., Clarke, L., Dahe, Q., Dasgupta, P., 2014. Climate Change 2014: Synthesis Report. Contribution of Working Groups I, II and III to the Fifth Assessment Report of the Intergovernmental Panel on Climate Change.

Parkin, T., Venterea, R., 2010. Sampling Protocols. Chapter 3. Chamber-based trace gas flux measurements. In: Follett, R.F. (Ed.), Sampling Protocols. http://www.ars.usda. gov/research/GRACEnet-Chamber-Based-Trace-Gas-Flux-Measurements-Protocol. (Accessed February 2011).

Qi, Z., Helmers, M.J., Malone, R.W., Thorp, K.R., 2011. Simulating long-term impacts of winter rye cover crop on hydrologic cycling and nitrogen dynamics for a cornsoybean crop system. T. Asabe 54, 1575-1588.

Qi, Z.M., Bartling, P.N.S., Jabro, J.D., Lenssen, A.W., Iversen, W.M., Ahuja, L.R., Ma, L. W., Allen, B.L., Evans, R.G., 2013. Simulating dryland water availability and spring wheat production in the Northern Great Plains. Agron. J. 105, 37-50.

Sanz-Cobena, A., Lassaletta, L., Aguilera, E., del Prado, A., Garnier, J., Billen, G., Iglesias, A., Sanchez, B., Guardia, G., Abalos, D., Plaza-Bonilla, D., PuigduetaBartolome, I., Moral, R., Galan, E., Arriaga, H., Merino, P., Infante-Amate, J., 
Meijide, A., Pardo, G., Alvaro-Fuentes, J., Gilsanz, C., Baez, D., Doltra, J., Gonzalez Ubierna, S., Cayuela, M.L., Menendez, S., Diaz-Pines, E., Le-Noe, J., Quemada, M., Estelles, F., Calvet, S., van Grinsven, H.J.M., Westhoek, H., Sanz, M.J., Gimeno, B.S., Vallejo, A., Smith, P., 2017. Strategies for greenhouse gas emissions mitigation in Mediterranean agriculture: a review. Agric. Ecosyst. Environ. 238, 5-24.

Schmer, M.R., Jin, V.L., Wienhold, B.J., Varvel, G.E., Follett, R.F., 2014. Tillage and residue management effects on soil carbon and nitrogen under irrigated continuous corn. Soil Sci. Soc. Am. J. 78, 1987-1996.

Stewart, C.E., Roosendaal, D.L., Sindelar, A., Pruessner, E., Jin, V.L., Schmer, M.R., 2019. Does No-tillage mitigate stover removal in irrigated continuous corn? A multilocation assessment. Soil Sci. Soc. Am. J. 83, 733-742.

Taft, H.E., Cross, P.A., Hastings, A., Yeluripati, J., Jones, D.L., 2019. Estimating greenhouse gases emissions from horticultural peat soils using a DNDC modelling approach. J. Environ. Manag. 233, 681-694.

Wang, H., Wang, S.L., Yu, Q., Zhang, Y.J., Wang, R., Li, J., Wang, X.L., 2020. No tillage increases soil organic carbon storage and decreases carbon dioxide emission in the crop residue-returned farming system. J. Environ. Manag. 261, 110261.
Wienhold, B.J., Schmer, M.R., Jin, V.L., Varvel, G.E., Gollany, H., 2016. CQESTR simulated changes in soil organic carbon under residue management practices in continuous corn systems. Bioenerg Res 9, 23-30.

Yang, H.S., Feng, J.X., Zhai, S.L., Dai, Y.J., Xu, M.M., Wu, J.S., Shen, M.X., Bian, X.M., Koide, R.T., Liu, J., 2016. Long-term ditch-buried straw return alters soil water potential, temperature, and microbial communities in a rice-wheat rotation system. Soil Till. Res. 163, 21-31.

Yang, W., Feng, G., Tewolde, H., Li, P.F., 2019. CO2 emission and soil carbon sequestration from spring-and fall-applied poultry litter in corn production as simulated with RZWQM2. J. Clean. Prod. 209, 1285-1293.

Yang, S., Sun, X., Ding, J., Jiang, Z., Liu, X., Xu, J., 2020a. Effect of biochar addition on CO2 exchange in paddy fields under water-saving irrigation in Southeast China. J. Environ. Manag. 271, 111029.

Yang, W., Feng, G., Read, J.J., Ouyang, Y., Han, J., Li, P., 2020b. Impact of cover crop on corn-soybean productivity and soil water dynamics under different seasonal rainfall patterns. Agron. J. 112 (2), 1201-1215.

Zhang, Z.Q., Qiang, H.J., McHugh, A.D., He, J., Li, H.W., Wang, Q.J., Lu, Z.Y., 2016. Effect of conservation farming practices on soil organic matter and stratification in a mono-cropping system of Northern China. Soil Till. Res. 156, 173-181. 